Vol. 13 (2004): 18-28.

\title{
Impact dehulling oat grain to improve quality of on-farm produced feed I. Hullability and associated changes in nutritive value and energy content
}

\author{
Pirjo Peltonen-Sainio, Markku Kontturi, Ari Rajala \\ MTT Agrifood Research Finland, Plant Production Research, FIN-31600 Jokioinen, Finland, \\ e-mail: pirjo.peltonen-sainio@mtt.fi \\ Anna-Maija Kirkkari \\ Work Efficiency Institute, PO Box 13, FIN-05201 Rajamäki, Finland
}

\begin{abstract}
High hull content of oat (Avena sativa L.) limits its use as on-farm feed. Dehulling, used in the oat processing industry, can be performed on-farm, to increase nutritive value and energy content. A laboratory model of an impact oat dehuller, similar to a commercial device, was used to study the effects of rotation speed, grain characteristics and moisture content on hullability and groat energy content. Grain of oat cultivar Salo [from official variety trials, MTT Agrifood Research Finland, Jokioinen $\left.\left(60^{\circ} 49^{\prime} \mathrm{N}\right), 1996-2000\right]$ was assessed for quality prior to dehulling. Impact dehulling rotation speed ranged from 200 to $500 \mathrm{r} \mathrm{min}^{-1}$ at $50 \mathrm{r} \mathrm{min}^{-1}$ intervals, with moisture content of grains ranging from $10 \%$ up to $18 \%$. Dehulling improved oat energy content markedly. Hullability was better at higher rotation speeds. $350 \mathrm{r} \mathrm{min}^{-1}$ was determined to be adequate to result in improved quality as no marked additional improvements were demonstrated by increasing rotation speed further. As the proportion of hulless groats increased with higher rotation speeds, nutritional and energy content of groat yield improved consistently. The higher the grain moisture, the higher the proportion of grains retaining hulls. Impact dehulling proved to be a potentially useful method to increase energy content of oat grains on-farm.
\end{abstract}

Key words: Avena sativa, fat, fibre, grain, groat, hulls, metabolizable energy, oats, proteins, rotational speed 
Vol. 13 (2004): 18-28.

\section{Introduction}

Nutritive value of oat (Avena sativa L.) grain is determined by two contrasting components: high quality groat encased by a hull, which resembles poor quality straw. The oat hull is mainly fibre; hemicellulose, cellulose and lignin. There are low levels of protein, fat, starch and watersoluble carbohydrates (Salo and Kotilainen 1970, Welch et al. 1983). As a result, digestibility of oat hull is low, ranging from 7 to $14 \%$ (Welch et al. 1983). For these reasons, high hull content of oat grain is the major determinant of decreasing nutritional quality, which is important if oat is used for feed.

Reducing the proportion of hulls in grain yield evidently results in marked increases in metabolised energy content when it is used for animal feed (Welch et al. 1983). Such changes are achieved by breeding for low hull content (Ronald et al. 1999). The composition of the hull can also be modified by breeding, but Welch et al. (1983) found that even though significant genetic differences in hull composition existed, the range was modest. Contrary to groat, both lemma and palea - the components of hull - are primarily formed before grain filling (Bonnett 1961). Thus, conditions unfavourable for grain filling result in incompletely filled grains and tend to reduce the groat to hull ratio. Ronald et al. (1999) indicated that groat weight correlated only modestly with proportion of hull and reported high broad-sense heritability estimates for hull percentage, which indicates the potential for selecting for reduced hull content.

Reduction in hull content is at the extreme in naked oat (A. sativa ssp. nuda L., Valentine 1987, Peltonen-Sainio 1997). The feed industry is not, however, necessarily receptive to receiving relatively small quantities of naked oat and is not willing to pay a bonus for it. Hence, naked oat is particularly attractive for on-farm use to substitute for other cereal grains with lower energy content (Valentine 1987, Peltonen-Sainio et al. 2004a). The latest naked oat cultivars are high yielding and, even though the unprotected groat is sensitive to damage (Peltonen-Sainio et al. 2001), no problems of storability were recorded when comparing naked and conventional oat (Welch 1977). Uncertainty in producing sufficiently viable seed does not, however, encourage the seed merchants to invest in naked oat, which consequently limits farmers' prospects to base their on-farm feed production on naked oat (Peltonen-Sainio et al. 2004a).

As an alternative to naked oat, hulls can be separated from groats by dehulling grain prior to feeding to animals. This method, extensively used in the oat processing industry, is also performed on-farm. The farmer can either invest in an oat dehuller or have dehulling done as an external service. These experiments were carried out to investigate the effects of adjustments, particularly rotation speed, on an impact oat dehuller as well as grain size and moisture content on hullability and the consequent nutritional content and energy value of the resultant oat grain.

\section{Material and methods}

Grain of oat cultivar Salo was obtained from official variety trials carried out at MTT Agrifood Research Finland, Jokioinen $\left(60^{\circ} 49^{\prime} \mathrm{N}\right)$ in $1996-$ 2000. In each year, net plot size was $12.5 \mathrm{~m}^{2}$ and 500 viable seeds were sown per square meter. $100 \mathrm{~kg}$ of $\mathrm{N} \mathrm{ha}^{-1}$, as $\mathrm{NH}_{4} \mathrm{NO}_{3}$, was applied at sowing. Weeds were chemically controlled and other recommended management procedures were followed (for further details, see Kangas et al. 2001). Grain from each year was pre-purified by sorting with $1.5 \mathrm{~mm}$ sieves to remove immature grains, small particles, dust and weed seeds prior to all measurements and analyses.

\section{Rotation speed effects of impact oat dehuller (Experiment I)}

Ten kilograms of pre-purified grains of oat cultivar Salo from 2000 were used as raw material 


\section{Peltonen-Sainio, P. et al. Impact dehulling oat grain: hullability, nutritive value and energy content}

for the experiment. Three $250 \mathrm{~g}$ sub-samples were dehulled at rotation speeds of 200, 250, $300,350,400,450$ and $500 \mathrm{r} \mathrm{min}^{-1}$ with an impact oat dehuller (Rivakka, Nipere Ltd., Finland, http://www.nipere.fi). The impact dehuller used in these experiments is a scale model of the commercial device used to dehull oat prior to feeding for animals. The Rivakka oat dehuller removes the hulls from the grain by centrifugal force and impact against a rubber covered chamber wall minimising damage to the groat. After the impact dehulling, groats and hulls fall into the vertical 'pipe' where they are separated by aspiration created with a vacuum cleaner (Eurovac). For better separation of groats and hulls the sample was further aspirated with a Saatmeister Kurt Pelz aspirator.

Mean single grain weight $(\mathrm{mg})$, hectolitre weight $(\mathrm{kg})$ and grain moisture content $(\%)$ were measured from three replicate samples prior to dehulling. Hull content (\%) was measured on three grain samples of 5 grams, dehulled by hand and weighing of the hulls and dividing their weight by the original weight of the non-dehulled grains. Dry matter (DM) content of non-dehulled grains and flour, and raw protein, fat, fibre and ash content (\%) of non-dehulled grains were carried out according to standard methods at the Chemistry Laboratory of MTT Animal Science. Metabolised energy content (ME) for ruminants [1] and poultry [2] and net energy content (NE) for pigs [3] were calculated as follows:
[1] $\mathrm{ME}\left(\mathrm{MJ} \mathrm{kg}^{-1} \mathrm{DM}\right)=(15.2 \times \mathrm{MRP}+34.2 \times$ $\mathrm{MRFa}+12.8 \times \mathrm{MRFi}$ $+15.9 \times \mathrm{MNNE}) / 1000$
[2] $\mathrm{ME}\left(\mathrm{MJ} \mathrm{kg}^{-1} \mathrm{DM}\right)=(18.03 \times \mathrm{MRP}+38.83$ $\times \mathrm{MRFa}+17.32 \times$ MNNE) $/ 1000$

[3] $\mathrm{NE}\left(\mathrm{MJ} \mathrm{kg}^{-1} \mathrm{DM}\right)=(10.8 \times \mathrm{MRP}+36.1 \times$ $\mathrm{MRFa}+6.3 \times \mathrm{MRFi}+$ $12.7 \times \mathrm{MNNE}) / 1000$,

in which MRP is metabolised raw protein $\left(\mathrm{g} \mathrm{kg}^{-1}\right.$ $\mathrm{DM}), \mathrm{MRF}$ is metabolised raw fat $\left(\mathrm{g} \mathrm{kg}^{-1} \mathrm{DM}\right)$, MRFi is metabolised raw fibre $\left(\mathrm{g} \mathrm{kg}^{-1} \mathrm{DM}\right)$ and MNNE is metabolised non-nitrogenous extracts ( $\left.\mathrm{g} \mathrm{kg}^{-1} \mathrm{DM}\right)$. MNNE [4] was calculated as: $\begin{aligned} {[4] \mathrm{MNNE}\left(\mathrm{g} \mathrm{kg}^{-1} \mathrm{DM}\right)=} & {[1000-(\mathrm{RP}+\mathrm{RFa}+} \\ & \mathrm{RFi}+\mathrm{ASH})] \times 0.91,\end{aligned}$

in which RP is raw protein content, $\mathrm{RFa}$ is raw fat content, RFi is raw fibre content and ASH is ash content all converted to $\mathrm{g} \mathrm{kg}^{-1} \mathrm{DM}$. The calculations are based on Schiemann et al. (1972) and Kaustell et al. (1997).

After dehulling, groat yield (g) and wastage $(\mathrm{g})$ were weighed and their relative proportions (\%) calculated. Groat yield consisted of groats that were liberated from hulls and either unbroken or broken and grains that retained their hulls. A $50 \mathrm{~g}$ sub-sample representing groat yield was analysed for hulls retaining grains ( $\mathrm{g}$ ) and their relative proportion on groat yield was calculated. Hull content (\%) of hulls retaining grains was measured after separating hull from groat by hand with a needle. Their relative proportions (\%) were calculated. The remaining groat yields from each of dehulled sub-samples subjected to different rotation speeds were used for analysing chemical composition [raw protein, fat, ash, and fibre contents (\%)] carried out according to standardised methods at Chemistry Laboratory of MTT Animal Science. Metabolised energy content for ruminants and poultry and NE content for pigs were calculated.

\section{Effects of year on grain hullability and quality of groats (Experiment 2)}

Mean single grain weight (mg), hectolitre weight $(\mathrm{kg})$ and grain moisture content $(\%)$ were analysed prior to dehulling from three replicate samples of pre-purified grain of oat cultivar Salo harvested in 1996-2000. Hull content (\%) was measured as in Experiment 1. Three sub-samples, each weighing $500 \mathrm{~g}$, were dehulled with a Nipere dehuller using a rotation speed of $350 \mathrm{r}$ $\mathrm{min}^{-1}$, which was fixed on the basis of the results obtained from Experiment 1. Analyses of DM content of whole grains and whole grain flour, as well as of protein, fat, fibre and ash content $(\%)$ of grains and dehulled groats were carried out according to standardized methods 
Vol. 13 (2004): 18-28.

at the Chemistry Laboratory of MTT Animal Science. Metabolised energy content for ruminants and poultry and NE content for pigs were calculated as in Experiment 1. Proportions of groat yield and wastage and hulls retaining grains in groat mass were measured as in Experiment 1.

\section{Effects of grain moisture on dehulling capacity (Experiment 3)}

After determining the moisture content of grain from 2000, three $180 \mathrm{~g}$ grain samples for each of the nine targeted grain moisture content classes were placed in plastic bottles. The amount of water resulting in grain moisture contents ranging from about 10 to $18 \%$ were calculated and added to the bottles, which were sealed and shaken overnight. The grain moisture content was measured and nine moisture content classes were determined: $10.3-10.5 \%$ (depending on treated sub-sample), $11.4-11.5 \%, 12.4-12.5 \%, 13.2-$ $13.5 \%, 14.1-14.4 \%, 15.4-15.5 \%, 16.3-16.4 \%$, $17.3-17.4 \%$ and $18.5-18.7 \%$. Three replicate samples per moisture content class, each weighing $150 \mathrm{~g}$, were dehulled at a rotation speed of $350 \mathrm{r} \mathrm{min}^{-1}$. Proportions of groat yield and wastage were measured and dehulled groat yield was analysed for hulls retaining grains as in Experiment 1 .

An additional experiment was carried out to monitor the moisture distribution between hull and groat of artificially moisturised grain samples. Prior to moisturising, grain moisture content $(\%)$ was measured. Three $150 \mathrm{~g}$ subsamples were hulled using an impact dehuller (Rivakka, Nipere Ltd) with a rotation speed of $350 \mathrm{r} \mathrm{min}^{-1}$. The moisture contents of groats and hulls were measured as described above for whole grains. Three grain subsamples with moisture contents of $11.1 \%, 14.1-14.2 \%$ (depending on treated sub-sample) and $18.2-18.3 \%$ were produced as previously. Three replicate samples per moisture content class, each weighing $50 \mathrm{~g}$, were dehulled by hand, and three replicate samples, each weighing $130 \mathrm{~g}$, were dehulled using a Rivakka oat dehuller with a rotation speed of $350 \mathrm{r} \mathrm{min}^{-1}$. The moisture contents of groats and hulls were measured as described above for whole grains.

\section{Statistical analysis}

Significant differences among years, grain moisture contents and effects of different rotation speeds of the dehuller were established using PROC MIXED software (Littell et al. 1996). Data were considered to be completely randomised (three replicates). In the model, different grain moisture contents, rotation speeds and years were considered as fixed effects. Correlation analyses were conducted (PROC CORR of SAS) for data from the long-term oat trials to establish the relationship between groat and hull weight.

\section{Results}

\section{Rotation speed effects on hullability and groat quality}

The higher the rotation speed of the impact oat dehuller, the lower the groat yield and the higher the proportion of wastage (Fig. 1). The increase in proportion of wastage and concomitant decrease in groat yield were most marked, averaging 8 percentage units, when rotation speed increased from 200 to $250 \mathrm{r} \mathrm{min}^{-1}$. Thereafter the change was $<3$ percentage units for each $50 \mathrm{r} \mathrm{min}^{-1}$ increase in rotation speed. At high rotation speeds, fewer hulls were left in the groat mass. At $200 \mathrm{r} \mathrm{min}^{-1}$ almost $60 \%$ of grains retained their hulls, while at rotation speed $\geq 400$ $\mathrm{r}$ min $^{-1}$ more than $97 \%$ were dehulled. Hull content of grains with hulls tended to increase until 350-400 $\mathrm{r} \mathrm{min}^{-1}$, but at higher rotation speeds dehulling was complete.

As dehulling resulted in a marked decrease in fibre content of the groat yield, nutritive value improved significantly (Fig. 2, Table 1). When compared with intact grains of cv. Salo, protein 
Peltonen-Sainio, P. et al. Impact dehulling oat grain: hullability, nutritive value and energy content
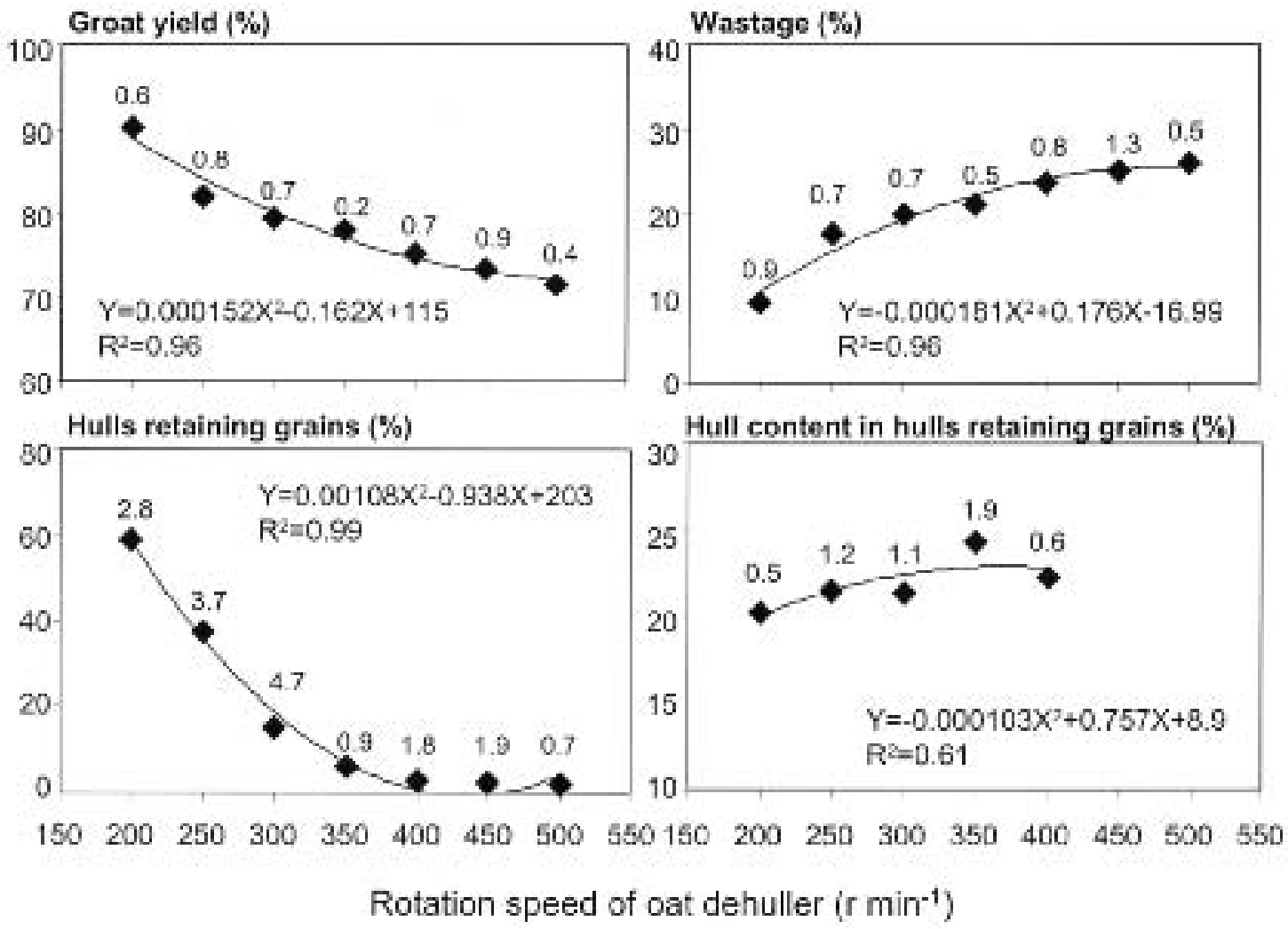

Fig. 1. Effects of rotation speed of the impact oat dehuller on proportion of groat yield, wastage and hulls retaining grains and hull content of unhulled grains from 2000. Standard deviations are shown as values next to each legend.

and fat contents increased from 12.7 to $15.6 \%$ and 5.4 to $6.3 \%$, respectively, and ash content decreased at most from 3.2 to $2.4 \%$ (data not shown) when impact dehulled. These changes in grain composition following dehulling markedly increased the calculated digestible energy content of oat: from 13.3 to $14.2 \mathrm{MJ} \mathrm{kg}^{-1} \mathrm{DM}, 10.7$ to $11.7 \mathrm{MJ} \mathrm{kg}^{-1} \mathrm{DM}$ and 14.3 to $15.7 \mathrm{MJ} \mathrm{kg}^{-1}$ DM when calculated for ruminants, pigs and poultry, respectively.

\section{Grain characteristic and moisture content effects on hullability and groat quality}

Growing conditions varied greatly between 1996 and 2000 and resulted in differences in duration of pre- and post-heading periods and quantity and quality of the grains produced by cv. Salo (Table 1). Quality of the grains subjected to dehulling at a constant rotation speed of $350 \mathrm{r}$ $\mathrm{min}^{-1}$ affected hullability and quality of the groat mass (Tables 2 and 3). The relative proportions of groat yield versus wastage differed among years, the difference being 8 percentage units at most (Table 3). Proportion of groats following dehulling was not associated with either single grain $\left(\mathrm{R}^{2}=0.07\right)$ or single groat weight $\left(\mathrm{R}^{2}=\right.$ 0.01 ) when results from only five years were compared. However, this evidently limited data tentatively indicated that groat yield was correlated with hectolitre weight $\left(\mathrm{R}^{2}=0.98\right)$, grain yield $\left(\mathrm{R}^{2}=0.90\right)$, hull content $\left(\mathrm{R}^{2}=0.51\right)$ and length of grain filling period $\left(R^{2}=0.45\right)$. Use of 
Vol. 13 (2004): 18-28.
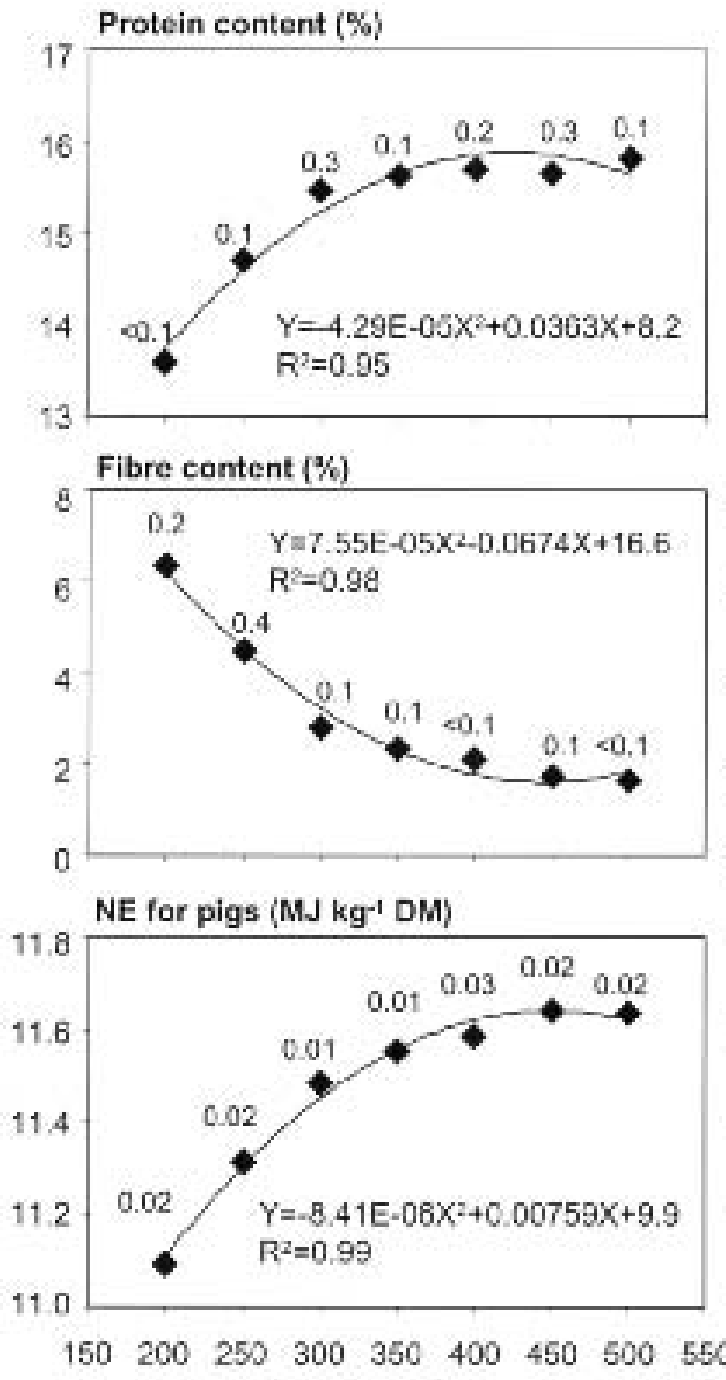
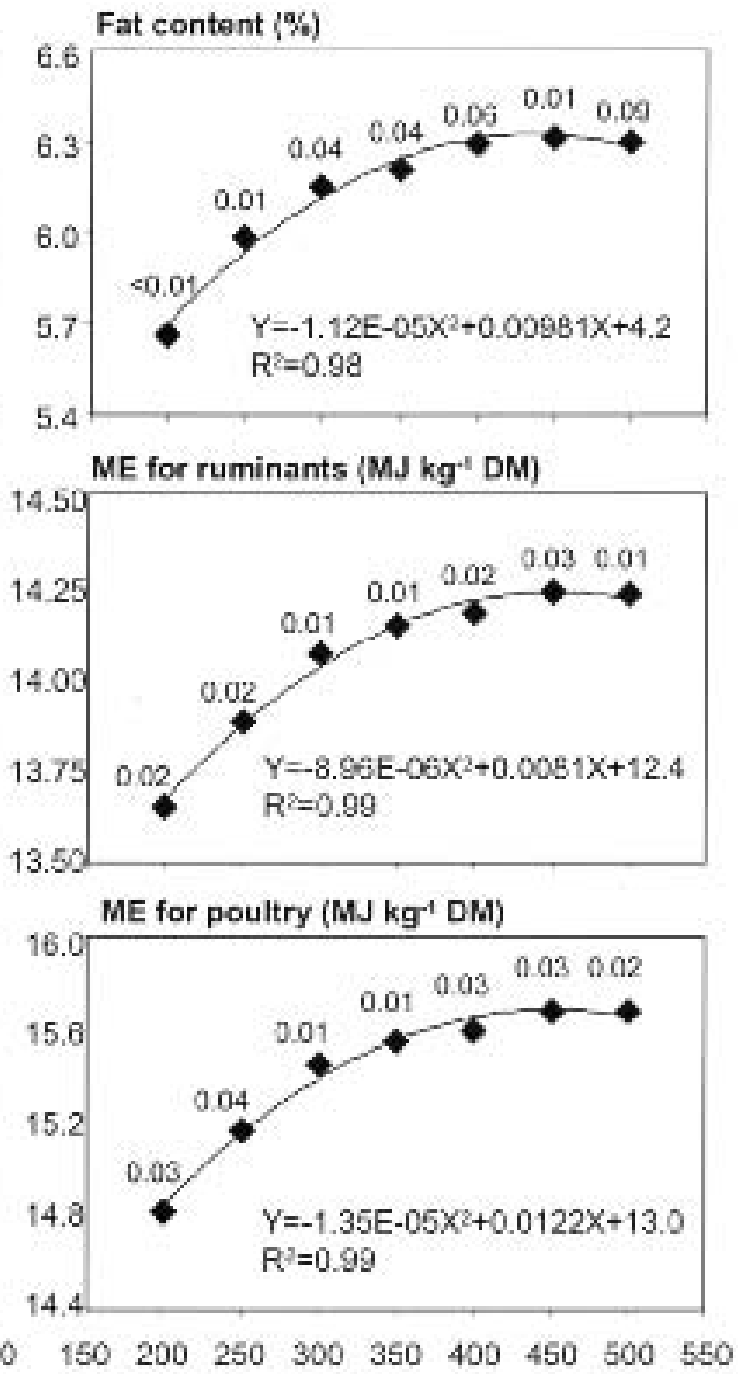

Rotation speed of oat dehuller $\left\langle\mathrm{r} \mathrm{min} \mathrm{m}^{-1}\right\rangle$

Fig. 2. Effects of rotation speed of the impact oat dehuller on protein, fat and fat content of groat yield and the calculated metabolised energy content for ruminants and poultry and net energy content for pigs (2000 trial). Standard deviations are shown as values next to each legend.

an additional data set (509 cases, several oat cultivars grown in official variety trials carried out in Jokioinen, MTT between 1970 and 2001) showed that the association between single groat weight and single hull weight was rather weak $\left(\mathrm{R}^{2}=0.15\right.$, Fig. 3$)$. Proportion of unhulled grains differed by more than 20 percentage units depending on year (Table 3 ).

Even though impact dehulling improved feed value markedly in each year, it neither narrowed nor extended the variation among years in nutritional quality of groat mass when compared with 
Peltonen-Sainio, P. et al. Impact dehulling oat grain: hullability, nutritive value and energy content

Table 1. Composition and the calculated digestible energy content for ruminants, pigs and poultry of intact oat grains and days to heading, length of grain-filling period and grain yield of oat cultivar Salo grown in official variety trials at Jokioinen in 1996-2000.

\begin{tabular}{|c|c|c|c|c|c|c|}
\hline Trait & 1996 & 1997 & 1998 & 1999 & 2000 & Mean \\
\hline \multicolumn{7}{|l|}{ Quality } \\
\hline Grain moisture content (\%) & 9.4 & 8.7 & 9.9 & 7.9 & 9.1 & 9.0 \\
\hline Single grain weight (mg) & 37.2 & 38.1 & 32.0 & 38.4 & 38.7 & 36.9 \\
\hline Hectolitre weight $(\mathrm{kg})$ & 47.9 & 47.9 & 45.2 & 42.5 & 47.7 & 46.2 \\
\hline Hull content (\%) & 24.9 & 23.5 & 24.6 & 26.2 & 22.5 & 24.3 \\
\hline Raw protein content $(\%)$ & 11.4 & 13.4 & 11.3 & 16.0 & 12.7 & 13.0 \\
\hline Raw fat content (\%) & 5.3 & 4.7 & 5.8 & 4.7 & 5.4 & 5.2 \\
\hline Raw fibre content $(\%)$ & 11.2 & 10.0 & 11.6 & 11.8 & 9.6 & 10.8 \\
\hline Ash content $(\%)$ & 3.87 & 3.82 & 3.51 & 4.05 & 3.21 & 3.69 \\
\hline ME for ruminants (MJ kg-1 DM) & 13.0 & 13.0 & 13.1 & 12.7 & 13.3 & 13.0 \\
\hline $\mathrm{NE}$ for pigs $\left(\mathrm{MJ} \mathrm{kg}^{-1} \mathrm{DM}\right)$ & 10.5 & 10.5 & 10.6 & 10.2 & 10.7 & 10.5 \\
\hline ME for poultry (MJ kg-1 DM) & 13.9 & 14.0 & 14.0 & 13.6 & 14.3 & 14.0 \\
\hline \multicolumn{7}{|l|}{ Growth $^{1)}$} \\
\hline Days to heading & 59 & 48 & 58 & 52 & 58 & 55 \\
\hline Length of grain-filling period (d) & 44 & 50 & 54 & 30 & 57 & 47 \\
\hline Grain yield $\left(\mathrm{g} \mathrm{m}^{-2}\right)$ & 533 & 591 & 484 & 121 & 571 & 460 \\
\hline
\end{tabular}

NE, net energy; ME, metabolised energy; DM, dry matter

1) Kangas et al. (2001)

Table 2. Groat yield, proportion of wastage and hullability of impact dehulled oat grown in 1996-2000 using a fixed rotation speed of $350 \mathrm{r} \mathrm{min}^{-1}$.

\begin{tabular}{lcrc}
\hline Year & \multicolumn{2}{c}{ Proportion (\%) } & $\begin{array}{c}\text { Hulls retaining } \\
\text { grains (\%) }\end{array}$ \\
\cline { 2 - 3 } & Groat yield & Wastage & \\
\hline 1996 & $79.2 \mathrm{a}$ & $20.8 \mathrm{c}$ & $26.8 \mathrm{a}$ \\
1997 & $79.5 \mathrm{a}$ & $20.5 \mathrm{c}$ & $16.9 \mathrm{~b}$ \\
1998 & $75.7 \mathrm{~b}$ & $24.3 \mathrm{~b}$ & $19.8 \mathrm{~b}$ \\
1999 & $71.6 \mathrm{c}$ & $28.4 \mathrm{a}$ & $17.6 \mathrm{~b}$ \\
2000 & $78.0 \mathrm{a}$ & $22.0 \mathrm{c}$ & $5.8 \mathrm{c}$ \\
Mean & 76.8 & 23.2 & 17.4 \\
\hline
\end{tabular}

Means within each column not followed by the same letter are significantly different at $\mathrm{P} \leq 0.05$.

that of the original grain yield (Table 3). For example, median protein content of oat grains was $13.7 \% \pm 17 \%$ and fat content $5.3 \% \pm 10 \%$, while in groat mass it was $16.5 \% \pm 18 \%$ and $6.4 \% \pm 13 \%$, respectively, at a constant impact dehuller rotation speed of $350 \mathrm{r} \mathrm{min}{ }^{-1}$. Similar-

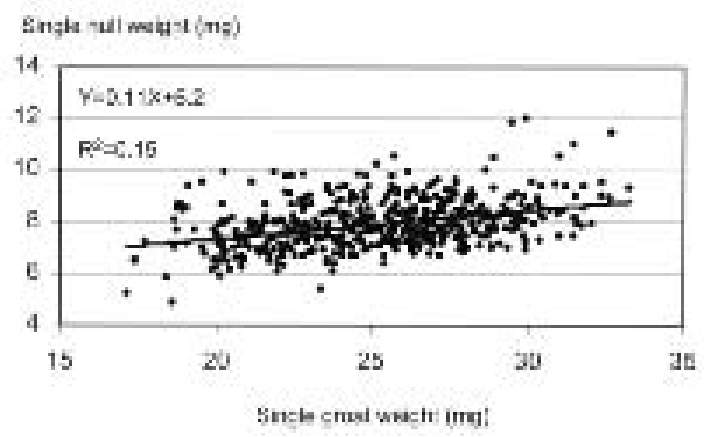

Fig. 3. Association between single groat weight and single hull weight according to official variety trials with several oat cultivars grown in Jokioinen in 1970-2001 $(n=509)$.

ly, the median for calculated NE for pigs was $10.5 \mathrm{MJ} \mathrm{kg}^{-1} \mathrm{DM} \pm 2 \%$, ME for poultry $14.0 \mathrm{MJ}$ $\mathrm{kg}^{-1} \mathrm{DM} \pm 3 \%$ and $\mathrm{ME}$ for ruminants $13.0 \mathrm{MJ}$ $\mathrm{kg}^{-1} \mathrm{DM} \pm 2 \%$ in oat grains and $11.4 \mathrm{MJ} \mathrm{kg}^{-1}$ $\mathrm{DM} \pm 2 \%, 15.3 \mathrm{MJ} \mathrm{kg}^{-1} \mathrm{DM} \pm 2 \%$ and $13.9 \mathrm{MJ}$ $\mathrm{kg}^{-1} \mathrm{DM} \pm 1 \%$ in groat mass, respectively. 
Vol. 13 (2004): 18-28.

Table 3. Protein, fat and fibre content and calculated energy content and improvement in energy content relative to unhulled grains (in parentheses) for ruminants, pigs and poultry of dehulled oat groat yield (1996-2000).

\begin{tabular}{|c|c|c|c|c|c|c|}
\hline \multirow[t]{2}{*}{ Year } & \multicolumn{2}{|c|}{ Content $(\%)$} & \multirow[b]{2}{*}{ Fibre } & \multicolumn{3}{|c|}{ Metabolised energy (MJ kg-1 DM) } \\
\hline & Protein & Fat & & Ruminants & Pigs & Poultry \\
\hline 1996 & $13.5 \mathrm{~d}$ & $6.4 \mathrm{~b}$ & $5.0 \mathrm{a}$ & $13.9 \mathrm{~b}(1.07)$ & 11.4 b (1.09) & $15.2 \mathrm{c}(1.09)$ \\
\hline 1997 & $16.0 \mathrm{~b}$ & $5.6 \mathrm{e}$ & $3.4 \mathrm{c}$ & 13.9 b (1.07) & $11.3 \mathrm{c}(1.08)$ & $15.3 \mathrm{c}(1.09)$ \\
\hline 1998 & $13.4 \mathrm{~d}$ & $7.2 \mathrm{a}$ & $4.4 \mathrm{~b}$ & $14.1 \mathrm{a}(1.08)$ & $11.6 \mathrm{a}(1.09)$ & $15.4 \mathrm{~b}(1.10)$ \\
\hline 1999 & $19.5 \mathrm{a}$ & $5.8 \mathrm{~d}$ & $4.3 \mathrm{~b}$ & 13.7 c (1.08) & $11.1 \mathrm{~d}(1.09)$ & $15.1 \mathrm{~d}(1.11)$ \\
\hline 2000 & $15.6 \mathrm{c}$ & $6.2 \mathrm{c}$ & $2.3 \mathrm{~d}$ & $14.1 \mathrm{a}(1.06)$ & $11.6 \mathrm{a}(1.08)$ & 15.6 a $(1.09)$ \\
\hline Mean & 15.6 & 6.2 & 3.9 & 13.9 (1.07) & $11.4(1.09)$ & $15.3(1.09)$ \\
\hline
\end{tabular}

A fixed rotation speed of $350 \mathrm{r} \mathrm{min}^{-1}$ was used for dehulling. Means within each column not followed by the same letter are significantly different at $\mathrm{P} \leq 0.05$.

Table 4. Effects of grain moisture content prior to impact oat dehulling on groat yield, proportion of wastage and dehullability using a fixed rotation speed of $350 \mathrm{r} \mathrm{min}^{-1}$.

\begin{tabular}{lccc}
\hline \multirow{2}{*}{$\begin{array}{l}\text { Grain moisture } \\
\text { content }(\%)\end{array}$} & \multicolumn{2}{c}{ Proportion (\%) } & $\begin{array}{c}\text { Hulls retaining } \\
\text { grains (\%) }\end{array}$ \\
\cline { 2 - 3 } & Groat yield & Wastage & \\
\hline 10.4 & $77.6 \mathrm{e}$ & $22.4 \mathrm{a}$ & $8.9 \mathrm{f}$ \\
11.5 & $78.8 \mathrm{~d}$ & $21.2 \mathrm{~b}$ & $15.2 \mathrm{de}$ \\
12.4 & $79.6 \mathrm{~d}$ & $20.4 \mathrm{bc}$ & $16.4 \mathrm{~d}$ \\
13.3 & $80.6 \mathrm{c}$ & $19.4 \mathrm{~d}$ & $19.6 \mathrm{bcd}$ \\
14.2 & $80.6 \mathrm{c}$ & $19.4 \mathrm{~d}$ & $23.3 \mathrm{bc}$ \\
15.4 & $81.8 \mathrm{bc}$ & $18.2 \mathrm{e}$ & $25.4 \mathrm{abc}$ \\
16.4 & $82.9 \mathrm{a}$ & $17.1 \mathrm{f}$ & $27.6 \mathrm{ab}$ \\
17.4 & $83.4 \mathrm{a}$ & $16.6 \mathrm{f}$ & $30.5 \mathrm{a}$ \\
18.6 & $82.8 \mathrm{a}$ & $17.2 \mathrm{f}$ & $24.9 \mathrm{abc}$ \\
\hline
\end{tabular}

Means within each column not followed by the same letter are significantly different at $\mathrm{P} \leq 0.05$.
Artificially moisturising the grains to $10-$ $19 \%$ prior to dehulling indicated that the higher the moisture content of the grains, the more difficult was dehulling (Table 4), while the proportion of broken groats was drastically decreased. The only exception to this trend was when increasing the moisture content from 17.4 to $18.6 \%$, which seemed to be a turning point in this trend. The proportion of groat yield increased, while that of wastage decreased at higher grain moisture content. An additional study indicated that the artificial moisturising method did not necessarily fully provide results comparable to those of dried and stored grains, as moisture content of hulls increased more relative to that of groats when artificially moistened (Table 5).

Table 5. Moisture distribution between groat and hull in dried and stored grains (control) compared to that in artificially moistened grains when dehulled with impact dehuller.

\begin{tabular}{|c|c|c|c|c|c|}
\hline \multirow{2}{*}{$\begin{array}{l}\text { Grain moisture content }(\%) \\
\text { after artificial moistening }\end{array}$} & \multicolumn{3}{|c|}{ Moisture content (\%) } & \multicolumn{2}{|c|}{ Proportion $(\%)$} \\
\hline & Hull & Groat & $\begin{array}{l}\text { Hull to } \\
\text { groat ratio }\end{array}$ & Groat yield & Wastage \\
\hline Untreated control (10.9) & $10.1 \mathrm{c}$ & $11.3 \mathrm{c}$ & $0.89 \mathrm{c}$ & $78.2 \mathrm{c}$ & $21.8 \mathrm{a}$ \\
\hline Treatment control (11.1) & $10.0 \mathrm{c}$ & $11.4 \mathrm{c}$ & $0.87 \mathrm{c}$ & $78.6 \mathrm{c}$ & $21.4 \mathrm{a}$ \\
\hline $14.1-14.2$ & $14.2 \mathrm{~b}$ & $14.0 \mathrm{~b}$ & $1.02 \mathrm{~b}$ & $80.7 \mathrm{~b}$ & $19.3 \mathrm{~b}$ \\
\hline $18.2-18.3$ & $18.7 \mathrm{a}$ & $18.7 \mathrm{a}$ & $1.04 \mathrm{a}$ & $82.4 \mathrm{a}$ & $17.6 \mathrm{c}$ \\
\hline
\end{tabular}

Means within each column not followed by the same letter are significantly different at $\mathrm{P} \leq 0.05$. 


\section{Peltonen-Sainio, P. et al. Impact dehulling oat grain: hullability, nutritive value and energy content}

\section{Discussion}

Feeding oat grains into the impact dehuller consistently improved nutritive value and energy content of oat (Fig. 2, Table 3). The increase in calculated metabolisable energy content was most prominent (9-10\%) for monogastric poultry and pigs, while at most some $7 \%$ increase was demonstrated for ruminants. Increase in energy content resulted mainly from a marked reduction in fibre content: from some $10 \%$ of intact grains to only about $2 \%$ in dehulled groats (Table 1, Fig. 2). Also the other important quality components, protein and fat, were increased markedly when grains were liberated from encapsulating hulls.

According to the manufacturer, the dehulling properties of the laboratory oat dehuller used in this study were the same as those of the commercial device (Pekka Viirimäki, Nipere Oy, personal communication, 22 January 2003). Oat grains are a particularly attractive target for dehulling as oat hulls drastically reduce the value of oat as a feed crop. Recorded changes in energy content - following dehulling induced valuable improvements in grain composition - resulting in an energy content comparable to that in naked oat and equal or better to that of wheat and barley (Valentine 1987, Doyle and Valentine 1988). Hence, these findings support the idea that the common problem of low energy content characteristic of on-farm cereal based feed, can be obviated through dehulling the oat grains. Dehulled groats are only different to naked oat in being richer in b-glucan (Givens et al. 2000). Thus, on-farm dehulling of conventional oat is an alternative to growing naked oat. An economic comparison incorporating energy value, average yield, dehulling costs and especially loss in dehulling (at least 20\%) is not, however, likely to show dehulled conventional oat to be a very competitive alternative for naked oat and barley.

Our results indicated that use of higher rotation speeds resulted in fewer hulls in the groat mass (Fig. 1). Hullability, ease of removal of the hull from the groat (Browne et al. 2002), deter- mined the quality of the groat yield (Fig. 2). On this basis, rotation speed of impact oat dehuller that results in adequate degree of dehulling and improvement in groat quality can be demonstrated, especially, as rotation speed was the major factor affecting groat to wastage ratio. Groat yield varied by up to 20 percentage units when the whole spectrum of rotation speeds was used (Fig. 1). Hullability mainly determined the amount of wastage. Almost full dehulling capacity was achieved using rotation speeds $\geq 400 \mathrm{r}$ $\mathrm{min}^{-1}$, and only $5 \%$ of the grains retained hulls at $350 \mathrm{r} \mathrm{min}^{-1}$. Hull content of groats retaining hulls increased at higher rotation speeds indicating a tendency of grains with higher hull content to have hulls particularly tightly bound to the groat. On the other hand, grains which did not dehull at low rotation speeds tended to have lower hull content than that of the intact grains. As the energy content of groat mass is closely associated with the amount of retaining hulls, the best rotation speed is primarily a compromise between degree of dehulling and groat breakage (Peltonen-Sainio et al. 2004b). This is particularly important if there is a risk of reduced storability resulting from increased groat damage. An impact oat dehuller rotation speed of 350 $\mathrm{r}$ min $^{-1}$ was regarded as best for the tested cultivar Salo as it resulted in high groat yield characterised by low proportion of hulled grains in conjunction with high energy content. As cultivars differed greatly and growing conditions had a large effect on hullability (Browne et al. 2002), the optimal rotation speed has to be determined separately for each cultivar. This is also supported by Doehlert et al. (1999), who found groat percentages of ten oat cultivars to differ by up to 6 percentage units when impact dehulled.

Quality of raw material used for dehulling contributed to hullability and quantity and quality of groat yield (Tables 2 and 3). Our experiment used grain of cultivar Salo from five years that differed in terms of growing conditions. There was an 8 percentage unit variation in groat yield and 21 percentage unit variation in proportion of unhulled grains at a fixed rotation speed of $350 \mathrm{r} \mathrm{min}-1$. As these data were limited and 
Vol. 13 (2004): 18-28.

did not allow broad conclusions to be drawn, we used long-term data to show that single groat weight was not strongly correlated with single hull weight (Fig. 3). This can be attributed to the time difference in their principal development phases of hulls (palea and lemma) versus groat (Bonnett 1961) in agreement with the finding of Ronald et al. (1999). This suggests that grain weight or hull content of oat provides only a rough estimate, if any, of groat mass to wastage ratio that can be realised with impact dehulling. This is further supported by the finding that over the five study years, in 1999 the lowest proportion of groat mass was associated with single grain weights far above the five-year average. However, groat yield correlated strongly with hectolitre weight. Doehlert et al. (1999) also did not find single grain weight to associate with groat yield from impact dehulling, but did find hectolitre weight and grain size uniformity to be correlated with groat percentage.

Grain moisture content slightly affected the proportion of groat yield (Tables 4 and 5), but the effect was less significant than that of year. Therefore, the recorded year effect on groat yield and wastage ratio was probably not merely due to differences in grain moisture content prior to dehulling. We found that proportion of hulls retaining grains increased with grain moisture content until approximately $17 \%$ was reached, after which it tended to decrease with further increasing moisture. This is in agreement with the findings of Doehlert and McMullen (2001).

The small grains tended to require higher rotation speeds to be released from hulls (Peltonen-Sainio et al. 2004b). Thus, for example, a large number of typically small sized tertiary grains (Palagyi 1983) in the grain mass might decrease hullability and require use of greater mechanical stress to yield groats with markedly improved metabolised energy content. Contrary to this, results of Browne et al. (2002) indicated that secondary grains were easier to dehull than primary grains, although this did not contribute to cultivar differences in hullability. Evidently, further studies are needed to establish the trait or combination of traits contributing to groat yield and wastage ratio and if associations are complex to construct a model for predicting quantity and quality of dehulled groat mass.

In conclusion, our results indicated that quality and energy content of oat grains improved markedly by impact dehulling. It is, however, of crucial importance that dehulled feed can be stored without problems such as rancidification of the groat mass.

Acknowledgements. The technical assistance of Arto Timonen and Aino Lahti at MTT Agrifood Research Finland is gratefully acknowledged.

\section{References}

Bonnett, O.T. 1961. The oat plant: its histology and development. University of Illinois, Agricultural Experiment Station, Bulletin 672. 112 p.

Browne, R.A., White, E.M. \& Burke, J.I. 2002. Hullability of oat varieties and its determination using a laboratory dehuller. Journal of Agricultural Science 138: 185-191.

Doehlert, D.C. \& McMullen, M.S. 2001. Optimizing conditions for experimental oat dehulling. Cereal Chemistry 78: 675-679.

Doehlert, D.C., McMullen, M.S. \& Baumann, R.R. 1999. Factors affecting groat percentage in oat. Crop Science 39: 1858-1865.

Doyle, J.C. \& Valentine, J. 1988. Naked oats: an assessment of economic potential for livestock feed in the United Kingdom. Plant Varieties and Seeds 1:99-108.

Givens, D.I., Davies, T.W. \& Laverick, R.M. 2000. Dietary fibre fractions in hulled and naked winter oat grain: effects of cultivar and various agronomic factors. Journal of the Science of Food and Agriculture 80: 491496.

Kangas, A., Laine, A., Niskanen, M., Salo, Y., Vuorinen, M., Jauhiainen, L. \& Mäkelä, L. 2001. Results of official variety trials 1993-2000. MTT publications, Series $A$ 94. Jokioinen, Finland. 262 p.

Kaustell, K., Tuori, M. \& Huhtanen, P. 1997. Comparison of energy evaluation systems for dairy cow feeds. Livestock Production Science 51: 255-266.

Littell, R.C., Milliken, G.A., Stroup, W.W. \& Wolfinger, R.D. 1996. SAS system for mixed models. Cary, NC: SAS Institute Inc. 633 p.

Palagyi, A. 1983. Tertiary seed proportions in the grain yield of several oat varieties. Cereal Research Communications 11: 269-274.

Peltonen-Sainio, P. 1997. Groat yield and plant stand structure of naked and hulled oat under different nitrogen fertilizer and seeding rates. Agronomy Journal 89: 140-147. 
Peltonen-Sainio, P. et al. Impact dehulling oat grain: hullability, nutritive value and energy content

Peltonen-Sainio, P., Kirkkari, A.-M. \& Jauhiainen, L. 2004a. Characterising strengths, weaknesses, opportunities and threats in producing naked oat as a novel crop for northern growing conditions. Agricultural and Food Science 13: 212-228.

Peltonen-Sainio, P., Lehtinen, P., Kontturi, M., Rajala, A. \& Kirkkari, A.-M. 2004b. Impact dehulling oat grain to improve quality of on-farm produced feed 2. Groat breakage and storability. Agricultural and Food Science 13: 29-38.

Peltonen-Sainio, P., Muurinen, S., Vilppu, M., Rajala, A., Gates, F. \& Kirkkari, A.-M. 2001. Germination and grain vigour of naked oat in response to grain moisture at harvest. Journal of Agricultural Science, Cambridge 137: 147-156.

Ronald, P.S., Brown, P.D., Penner, G.A., Brûlé-Babel, A. \& Kibite, S. 1999. Heritability of hull percentage in oat. Crop Science 39: 52-57.
Salo, M.-L. \& Kotilainen, K. 1970. On the carbohydrate composition and nutritive value of some cereals. Journal of the Scientific Agricultural Society of Finland 42: 21-29.

Schiemann, R., Nehring, K., Hoffmann, L., Jentsch, W. \& Chudy, A. 1972. Energetische Futterbewertung und Energienormen. VEB Deutscher Landwirtschafsverlag Berlin. 344 p.

Valentine, J. 1987. Breeding cereals of high nutritional quality with special reference to oats and naked oats. Aspects of Applied Biology 15: 541-548.

Welch, R.W. 1977. The development of rancidity in husked and naked oats after storage under various conditions. Journal of the Science of Food and Agriculture 28: 269-274.

Welch, R.W., Hayward, M.V. \& Jones, D.I.H. 1983. The composition of oat husk and its variation due to genetic and other factors. Journal of the Science of Food and Agriculture 34: 417-426.

\title{
SELOSTUS
}

\section{Kotoisen kauran ravitsemuksellista arvoa ja energiapitoisuutta voidaan parantaa kuorinnalla}

\author{
Pirjo Peltonen-Sainio, Markku Kontturi, Ari Rajala ja Anna-Maija Kirkkari \\ MTT (Maa- ja elintarviketalouden tutkimuskeskus) ja Työtehoseura ry
}

Kauran kuori vastaa ravintoarvoltaan heikkolaatuista olkea, mikä heikentää huomattavasti kauran ravintoarvoa. Teollisuudesta tutulla kuorinnalla voidaan parantaa kotoisen kaurarehun laatua myös maatiloilla, tai kuorinta voidaan teettää kaupallisella kuorijalla. Tutkimuksessa selvitettiin, kuinka Rivakka-keskipakokuorijan (Nipere Oy) säädöt ja kuorittavan kauraraaka-aineen laatu vaikuttavat ydinsaantoon, hävikkiin sekä jyvien ravitsemukselliseen laatuun ja energiapitoisuuteen.

Kauran kuorintakokeet järjestettiin Maa- ja elintarviketalouden tutkimuskeskuksessa Jokioisilla. Virallisissa lajikekokeissa vuonna 2000 kasvatettua Salo-kauran jyväsatoa kuorittiin Rivakka-keskipakokuorijalla käyttäen useita kierrosnopeuksia (200-500 kierrosta minuutissa). Tutkimustulokset osoittivat, että kuoriutuvuus parani kierrosnopeuden lisääntyessä. Hyvä kuorintateho saavutettiin käyttämällä 350 kierrosta minuutissa, koska tällöin kuoriutumatta jääviä jyviä oli niukasti (alle $10 \%$ ) ja saatavan ydinsadon ravitsemuksellinen arvo sekä energiapitoisuus parantuivat huomattavasti kuorimattomaan kauraan verrattuna.

Tutkimuksessa tarkasteltiin myös kuorittavan kauraraaka-aineen ominaisuuksien merkitystä kuorintatulokseen. Eri satovuosien (1996-2000) Salo-kauraa kuorittiin vakionopeudella (350 kierrosta minuutissa). Lisäksi järjestettiin erillinen kostutuskoe, jossa tutkittiin kuinka jyvän kosteus vaikuttaa jyvien kuoriutuvuuteen. Kuorittavan raaka-aineen laatu vaikutti huomattavasti kuorintatulokseen. Jyväkoko tai kuoripitoisuus eivät kuitenkaan yksinään selittäneet kuoriutuvuutta. Mitä korkeampi jyvän kosteuspitoisuus oli, sitä heikommin jyvät kuoriutuivat. Normaaliin varastokosteuteen kuivattu sato kuoriutui jo riittävästi hyvän ravitsemuksellisen arvon varmistaakseen. Tutkimustulosten perusteella yhteenvetona voidaan todeta, että kauran keskipakokuorinta olennaisesti paransi kauran ravinto- ja energiapitoisuutta tarjoten varteenotettavan vaihtoehdon paljasjyväisen kauran viljelylle. 